\title{
PENINGKATAN KEMAMPUAN MEMAHAMI PERISTIWA DETIK-DETIK PROKLAMASI MELALUI METODE BERMAIN DRAMA PADA SISWA KELAS VIID SMPN 7 PENAJAM PASER UTARA
}

\author{
Mardiana Piliang \\ SMP Negeri 7 Penajam Paser Utara \\ Kelurahan Sotek Kecamatan Penajam Kabupaten Penajam Paser Utara \\ mardianapiliang5@gmail.com
}

\begin{abstract}
Sociodrama method is a method that is used to give understanding about social problems and also to develop students' ability to solve the problems (Sanjaya, 2012). The writer intended to to this research to encourage students of SMPN 7 PPU to play roles some Indonesian National heroes hence they can understand how is the Indonesian Proclamation moment. The design of this study is Classroom Action research (CAR) that was conducted in SMPN 7 PPU. The subject in this study are the Eight grade students of SMPN 7 PPU. According to the result of the research, it can be concluded that conducting sociodrama method can enhance SMPN 7 PPU students' PPKn learning result. It can be seen by the increasing of the mean score of the students from cycle 1, cycle 2 and cycle 3 , which was $64.4 \%$ to $71.1 \%$ and $78 \%$, which is above the standard, 71. This method can be considered as successful if $75 \%$ or more students pass the minimum score. In cycle 1, the students only watche their friends doing sociodrama, only $12.5 \%$ of students can pass the test. In cycle 2, half of students got involved in sociodrama and $50 \%$ of them got more than minimum score. The last, in the cycle 3, all of the students got involved in sociodrama and the percentage of students who passed the test is $87.5 \%$.
\end{abstract}

Keyword: Civil Subject, PPKn, Sociodrama Method, Indonesian Proclamation

\section{Pendahuluan}

Kebutuhan pendidikan merupakan kebutuhan pokok yang sangat dibutuhkan oleh semua lapisan masyarakat. Pendidikan memegang peran penting dalam upaya peningkatan kualitas sumber daya manusia karena pendidikan merupakan satusatunya wadah untuk menciptakan sumber daya manusia yang berkualitas. Melalui pendidikan akan menjadikan manusia berketerampilan serta mempunyai kemampuan yang tinggi. Oleh karena itu, pendidikan harus mendapatkan perhatian yang serius dan sunguguh-sungguh, baik pendidikan jalur sekolah maupun pendidikan diluar jalur sekolah.

Untuk menunjukkan perkembangan ilmu dan teknologi yang berorientasi pada kebutuhan masyarakat yang luas, diperlukan menusia yang berkualitas dan berpotensi dalam arti yang seluasluasnya, melalui pendidikan akan terjadi proses pendewasaan diri sehingga dalam proses pengambilan keputusan terhadap suatu masalah yang dihadapi selalu disertai dengan tanggung jawab.

Mengingat peran pendidikan tersebut, maka sudah seyogyanya aspek ini menjadi perhatian pemerintah dalam rangka meningkatkan sumber daya manusia Indonesia yang berkualitas. Upaya yang telah dilakukan untuk meningkatkan mutu pendidikan dalam mata pejaran PPKn SMP kelas dan kelas VIID pada khususnya adalah pembaharuan sistem pengajaran pada materi detikdetik proklamasi,yang mana belum sepenuhnya mencapai kualitas keberhasilan yang diharapkan. Kenyataan ini dapat dilihat dari kemampuan memahami peristiwa detik-detik proklamasi pada siswa masih rendah, sesuai hasil observasi awal yang dilakukan oleh penulis di SMPN 7 PPU kelas VIID ini.

Permasalahan ini timbul dikarenakan siswa yang kurang tertarik dengan metode yang diterapkan oleh guru. Komunikasi searah yang memaksa siswa membaca buku serta wajib menghapal setiap nama tokoh dan mengingat tanggal terjadinya peristiwa menjadikan peserta didik menjadi bosan. Maka dibutuhkanlah metode pembelajaran yang menarik yang melibatkan mental, fisik, serta sosial siswa. Oleh karena itu penulis bermaksud untuk menerapkan suatu tindakan alternatif. Tindakan alternatif yang penulis tawarkan adalah menggunakan metode pembelajaran bermain drama. Bermain drama merupakan metode pembelajaran yang menjadikan siswa tersebut sebagai pelaku sejarah. Diharapkan setelah siswa terlibat langsung dalam sejarah maka 
mereka akan mampu memahami peristiwa detikdetik proklamasi dengan baik.

\section{Pengertian Drama}

Kajian mengenai pengertian dan karakteristik bermain drama terdiri dua hal pokok yakni pengertian drama dan unsur drama. Menurut Jassin (Nugiantoro, $2007: 15$ ) drama bisa diartikan sebagai kisah hidup atau kehidupan manusia yang bersifat aktif maupun nyata. Drama ataupun teater adalah pertunjukan yang terjadi pada dunia manusia. Pelaku drama tentu manusia yang pandai berdrama. Berdrama artinya pandai memoles situasi, bisa berminyak air, bisa menyatakan yang tidak sebenarnya, dan imajinatif (Endraswara, 2011: 264)

Pendapat lain dikemukan oleh kosasih (2013) bahwa drama adalah pertunjukkan diatas panggung yang menghadirkan konflik antar tokohnya dengan gerak dan dialog. Dari pengertian tersebut dapat ditarik suatu simpulan bahwa drama adalah suatu lakon yang dipertokohkan diatas panggung oleh tokoh dengan media dialog.

Unsur-unsur yang harus diperhatikan dalam pementasan atau pertunjukan drama yaitu; 1. Tema

Tema adalah pikiran yang mendasari kisah drama, Pemikiran pokok tersebut dikembangkan sedemikian rupa dan menarik. Tema sendiri dapat dipersempit menjadi topic.kemudian topic tersebut dikembangkan menjadi kisah dalam drama dengan dialog-dialognya.

\section{Plot}

Plot atau alur adalah rangkaian peristiwa atau jalanya peristiwadengan tahap tahapannya.Adapun tahapan tersebut menurut Aristotelis (Munirah, 2007:5) menyatakan ;

a. Eksposisi: Tahap perkenalan tokoh melalui adegan-adegan dan dialog yang mengantarkan penonton pada keadaan yang nyata.

b. Konflik: Pada tahapan ini mulai ada permasalahan atau insiden yang melibatkan tokoh

c. Komplikasi: Insiden yang terjadi mulai berkembang dan konflik-konflik tersebut mulai rumit

d. Klimaks: Berbagai konflik telah sampai pada puncaknya atau puncak ketegangan bagi para penonton. e. Penyelesaian: Tahapan ini merupakan akhir penyelesaian konflik. Disini, ceritanya dapat berakhir menyenangkan,mengharukan, tragis,atau menimbulkan teka-teki bagi para penonton.

3. Penokohan

Penokohan dalam drama mencakup hal-hal sebagai berikut:

a. Aspek fisiologis: Aspek ini berkaitan dengan penamaan, pemeran, dan keadaan fisik tokoh.

b. Aspek Sosiologis: Aspek ini diberkaitan dengan keadaan sosial tokoh,yakni interaksi atau peran sosial tokoh dengan tokoh lain.

c. Aspek psikologis: Aspek ini berkaitan dengan karakter yaitu keseluruhan ciri-ciri jiwa atau kepribadian seorang tokoh.

4. Dialog

Dialog adalah percakapan antar tokoh yang bersamaan dalam suatu gerak atau adegan.

5. Bahasa

Bahasa merupakan bahan dasar naskah/scenario dalam wujud kata dan kalimat.

6. Ide dan Pesan

Ide dan pesan dalam pertunjukkan drama harus ditulis oleh penulis dan diimplementasikan oleh pemeran.

7. Setting

Setting atau latar adalah keadaan tempat dan suasana terjadinya suatua adegan dipanggung.

\section{Metode \\ 1. Desain Penelitian}

Penelitian ini adalah jenis penelitian dengan pendekatan campuran; kualitatif dan kuantitatif. Penelitian campuran (Mixed method) merupakan perpaduan antara metode penelitian kualitatif dan kuantitatif (Sugiyono, 2014). Penelitian ini bersifat kualitatif maksudnya datadata yang diperoleh dianalisis tidak dengan rumusrumus statistik untuk memperoleh simpulan, dalam hal ini lembar observasi saat sosiodrama dilakukan adalah instrument kualitatifnya. Penelitian kuantitatif adalah Penelitian dimana peneliti menetapkan apa yang akan diteliti, menetapkan rumusan masalah yang spesisifik, dan terbatas, mengumpulkan data-data berupa hasil pengukuran tes dari responden.

Desain dari penelitian ini adalah PTK (Penelitian Tindakan Kelas). Menurut Hopkins (dalam Wiriaatmadya, 2007: 11), PTK adalah 
penelitian yang mengkombinasikan prosedur penelitian dengan tindakan substantif, suatu tindakan yang dilakukan dalam disiplin inkuiri atau suatu usaha seseorang untuk memahami apa yang sedang terjadi, yang terlihat dalam sebuah proses perbaikan dan perubahan. Kemmis Dan Taggart (1988) menyatakan bahwa PTK sebagai bentuk refleksi diri kolektif yang didahulukan oleh para partisipan dalam situasi sosial dengan tujuan untuk meningkatkan produktivitas, rasionalitas, keadilan pada persoalan sosial, atau praktik pendidikan. PTK terdiri dari beberapa siklus dalam melaksanakannya untuk melihat perubahan yang terjadi terhadap metode yang diterapkan kepada partisipan.

\section{Subjek, Waktu, dan Lokasi Penelitian}

Penelitian ini dilaksanakan pada semester ganjil tahun pelajaran 2018/2019. Penelitian ini dilaksanakan di SMPN 7 PPU, dan yang menjadi subjek dalam penelitian ini adalah siswa kelas VIID SMPN 7 PPU, dengan jumlah siswa 24 orang pada semester ganjil tahun pelajaran 2018/2019.

\section{Prosedur Penelitian}

Penelitian Tindakan Kelas (PTK) ini direncanakan dan dilaksanakan pada semester ganjil pada tahun ajaran 2018/2019 yang dibagi kedalam tiga siklus, yaitu :

1. Siklus I, (2 kali pertemuan, 2 x 40 menit dan 1 x 40 menit )

a. Tahap rencana tindakan

Kegiatan-kegiatan yang dilakukan dalam tahap ini adalah sebagai berikut;

1. Melakukan diskusi dengan kepala sekolah pada sekolah lokasi penelitian untuk membahas yang akan dipecahkan.

2. Membuat rencana pembelajaran sesuai dengan kurikulum setiap pertemuan. Dalam pembuatan RPP ini akan dibuatkan soal-soal yang akan diberikan pada siswa.

3. Mengkaji kurikulum materi pembelajaran PPKn Kelas VIID yang akan diajarkan pada penelitian ini.

4. Menentukan pokok bahasan yang akan diajarkan.

5. Membuat format observasi mengenai kondisi belajar mengajar dikelas.

b. Tahap pelaksanaan tindakan
Secara umum tindakan yang akan dijabarkan sebagai berikut:

1. Guru membagikan naskah sosiodrama secara spontan untuk diperankan oleh siswa yang dipilih guru.

2. Siswa berusaha memerankan sosiodrama detik-detik proklamasi.

3. Siswa dapat bertanya-jawab/berdiskusi dengan sesama siswa atau guru untuk membahas sosiodrama yang diperankan secara spotan oleh siswa.

4. Pada setiap akhir pertemuan siswa akan diberikan tugas mengenai detik-detik proklamasi.

c. Tahap observasi.

Pada prinsipnya tahap observasi dilakukan selama penelitian berlangsung, melakukan pengamatan terhadap proses pelaksanaan tindakan dengan menggunakan lembar observasi yang telah dibuat yaitu dengan cara mengidentifikasi dan mencatat tingkat perkembangan siswa mengenai peristiwa detik-detik proklamasi dalam proses belajarmengajar untuk mengetahui peningkatan hasil belajar siswa setelah diterapkan pembelajaran dengan menggunakan metode bermain drama.

d. Tahap refleksi

Dari hasil yang telah diperoleh pada tahap observasi penelitian akan merefleksikandiri dengan melihat data observasi dan tes akhir. Hasil analisis data yang diperoleh dalam tahap ini akan digunakan sebagai acuan untuk melaksanakan siklus berikutnya. Adapun perbaikan-perbaikan yang dilakukan untuk meningkatkan hasil belajar siswa antara lain menyesuikan waktu yang telah tersedia dengan materi pelajaran yang akan diberikan. Motivasi dan dorongan kepada siswa masih berada pada tingkat penguasaan materi yang rendah, dan juga menugaskan siswa untuk mempelajari sosiodrama detik-detik proklamasi karena target hasil belajar kurang mamuaskan.

2. Siklus II, ( 2 kali pertemuan, $2 \times 40$ menit dan 1 X 40 menit )

Tiap siklus dilaksanakan sesuai dengan perubahan yang ingin dicapai. Untuk dapat mengetahui hasil belajar PPKn maka diberikan teks pada akhir pertemuan siklus I seterusnya direfleksi lagi di pertemuan kedua tiap siklus. Prosedur penelitian yang dilakukan 
mengikuti model Kemmiez end mee taggrat yang terdiri atas empat komponen yaitu, perencanaan, pelaksanaan, tindakan, observasi, dan refleksi.

Secara rinci langkah langkah yang akan dilakukan dalam pelaksanaan tindakan kelas ini dapat dijabarkan sebagai berikut.Siklus II berlangsung selama dua kali pertemuan. Kegiatan yang dilakukan pada siklus II ini adalah mengulang kegiatankegatan yang dilakukan pada siklus I namun dengan beberapa perubahan.

Berdasarkan desain PTK tersebut, peneliti melakukan:

1. Perencanaan (plan)

Dalam merencanakan tindakan, peneliti melakukan diantaranya:

a. Melakukan evaluasi untuk mengatasi masalah yang terjadi pada siklus I

b. Merumuskan strategi tambahan untuk membantu meningkatkan keaktifan siswa, seperti memberi pujian dan penghargaan bagi siswa yang aktif

c. Menentukan pokok bahasan yang diajarkan

d. Mempersiapkan perangkat pembelajaran yakni rencana pelaksanaan pembelajarn (RPP)

e. Membuat format observasi untuk mengetahui kondisi belajar mengajar siswa dikelas

2. Pelaksanaan (action)

Tahap pelaksanaan tindakan diantaranya:

a. Guru mempersilahkan kelompok siswa yang akan tampil untuk memperagakan sosiodrama mengenai detik-detik proklamasi.

b. Siswa-siswa yang lain memperhatikan sosiodrama mengenai detik-detik proklamasi.

c. Siswa dapat bertanya-jawab/berdiskusi dengan sesama siswa atau guru untuk membahas pertunjukan sosiodrama yang ditonton.

d. Pada setiap akhir pertemuan siswa akan diberikan tugas mengenai detik-detik proklamasi.

e. Dan akan di evaluasi di pertemuan berikut.

3. Observasi

Pada tahap ini kegiatan yang dilakukan adalah mengamati setiap aktifitas siswa selama proses belajar mengajar dengan menggunakan lembar observasi.

4. Refleksi

Dari hasil yang diperoleh pada tahap observasi dan evaluasi penelitian akan merefleksikan dengan melihat data observasi dan tes akhir.
Hasil analisis data yang diperoleh dalam tahap ini akan dipergunakan sebagai acuan untuk mengetaui apakah pembelajaran berhasil atau tidak. Adapun perbaikan-perbaikan yang akan dilakukan untuk meningkatkan hasil belajar antara lain; menyesuaikan waktu yang tersedia dengan materi yang diberikan, meminta seluruh kelompok siswa (dua kelompok) untuk membuat sosiodrama mengenai detik-detik proklamasi, guru juga diminta untuk memberikan motivasi dan dorongan kepada siswa yang masih berada pada tingkatan materi yang rendah.

3. Siklus III, ( 2 kali pertemuan, 2 x 40 menit dan $1 \times 40$ menit )

Tiap siklus dilaksanakan sesuai dengan perubahan yang ingin dicapai. Untuk dapat mengetahui hasil belajar PPKn maka diberikan teks pada akhir siklus II. Prosedur penelitian yang dilakukan mengikuti model Kemmis \& McTaggrat (1992) yang terdiri atas empat komponen yaitu, perencanaan, pelaksanaan, tindakan, observasi, dan refleksi.

Secara rinci langkah-langkah yang akan dilakukan dalam pelaksanaan tindakan kelas ini dapat dijabarkan sebagai berikut; siklus III berlangsung selama satu kali pertemuan. Kegiatan yang dilakukan pada siklus III ini adalah mengulang kegiatankegatan yang dilakukan pada siklus I namun dengan beberapa persiapan kedua kelompok sosiodrama kelas.

Berdasarkan desain PTK tersebut, peneliti melakukan:

1. Perencanaan (plan)

Dalam merencanakan tindakan, peneliti melakukan diantaranya:

a. Melakukan evaluasi untuk mengatasi masalah yang terjadi pada siklus I

b. Merumuskan strategi tambahan untuk membantu meningkatkan keaktifan siswa, seperti memberi pujian dan penghargaan bagi siswa yang aktif

c. Menentukan pokok bahasan yang diajarkan

d. Mempersiapkan perangkat pembelajaran yakni rencana pelaksanaan

pembelajaran (RPP)

e. Membuat format observasi untuk mengetahui kondisi belajar mengajar siswa

dikelas 


\section{Pelaksanaan (action)}

Tahap pelaksanaan tindakan diantaranya:

a. Guru mempersilahkan seluruh kelompok siswa (dua kelompok) yang akan tampil untuk memperagakan sosiodrama mengenai detik-detik proklamasi.

b. Siswa-siswa yang lain memperhatikan sosiodrama mengenai detik-detik proklamasi.

c. Siswa dapat bertanya-jawab/berdiskusi dengan sesama siswa atau guru untuk membahas pertunjukan sosiodrama yang ditonton.

d. Pada setiap akhir pertemuan siswa akan diberikan tugas mengenai detik-detik proklamasi.

3. Observasi

Pada tahap ini kegiatan yang dilakukan adalah mengamati setiap aktifitas siswa selama proses belajar mengajar dengan menggunakan lembar observasi.

4. Refleksi

Dari hasil yang diperoleh pada tahap observasi dan evaluasi penelitian akan merefleksikan dengan melihat data observasi dan tes akhir. Hasil analisis data yang diperoleh dalam tahap ini akan dipergunakan sebagai acuan untuk mengetaui apakah pembelajaran berhasil atau tidak.

\section{Teknik Pengumpulan Data}

Dalam memperoleh data penelitian, perlu dilakukan pengumpulan data. Adapun teknik pengumpulan data dalam penelitian ini diantaranya :

Jenis data yang didapatkan adalah data kualitatif dan kuantitatif yang terdiri dari:

a. Lembar observasi: data tentang situasi pembelajaran pada saat diadakan tindakan pembelajaran dengan sosiodrama.

b. Hasil belajar siswa: data tentang hasil belajar siswa diambil dengan menggunakan skor siswa tentang memahami peristiwa detik-detik proklamasi melalui tes essay.

\section{Teknik Analisis Data}

Data yang dikumpulkan akan dianalisis secara kualitatif dan kuantitatif. Data hasil observasi dianalisis secara kualitatif, sedangkan data hasil tes (Evaluasi) dianalisis secara kuantitatif. Sebelumnya nilai tes siswa tersebut dikategorikan sesuai KKM yang diterapkan oleh hasil musyawarah Kepala Sekolah dan guru-guru dan SMP Negeri 7 Penajam.

Perolehan skor dan kategori:

Skor $<70 \quad$ Kurang

Skor 71-80 Cukup

Skor 81-90 Baik

Skor 90-100 Sangat Baik

Kemudian penulis menggunakan teknik analisis deskriptif yang terdiri atas rataan (mean), nilai maksimum dan nilai minimum siswa yang diperoleh pada setiap siklus untuk menganalisa.

1. Rata-rata

Rata-rata digunakan untuk mengetahui hasil belajar siswa dalam satu kelas dan untuk mengetahui peningkatan hasil belajar dengan rnembandingkan rata-rata skor hasil belajar masing-masing siklus. Rumus yang digunakan adalah sebagai berikut:

$$
\bar{X}=\frac{x_{1}+x_{2}+x_{3}+\ldots+x_{i}}{n}=\frac{\sum_{i=1}^{n} X_{i}}{n}
$$

Keterangan:

$\bar{x} \quad=$ Nilai rata-rata hasil belajar siswa pada setiap siklus

$\mathrm{n} \quad=$ Banyaknya siswa

$\sum_{i=1}^{n} x_{i}=$ Jumlah skor seluruh siswa (Sudjana, 1996:67)

2. Persentase

Persentasi digunakan untuk menggambarkan peningkatan hasil belajar siswa dari siklus I ke siklus II dan dari siklus II ke siklus III dengan menggunakan rumus:

$$
\text { Persentasi }=\frac{a}{b} \times 100 \%
$$

Keterangan:

a $=$ Selisih skor rata-rata hasil belajar siswa pada tiga siklus

$\mathrm{b}=$ Skor rata-rata hasil belajar siswa pada siklus sebelumnya

\section{Indikator Keberhasilan Penelitian}

Penelitian Tindakan Kelas ini dapat dikatakan berhasil jika nilai hasil belajar siswa minimal 71 (Kategori tinggi), hal ini dikarenakan KKM mata pelajaran PPKn kelas VII SMP Negeri 7 Penajam adalah 71. Dan untuk ketuntasan secara presentase adalah $75 \%$ anak mendapat nilai KKM atau diatas KKM. Dengan kata lain jika prosentase ketuntasan kelas lebih dari $75 \%$, maka penelitian akan dihentikan, dengan demikian siklus berikutnya ditiadakan. 


\section{Hasil Dan Pembahasan}

\section{Siklus I}

\section{a. Hasil Observasi}

Dalam pelaksanaan pembelajaran PPKn pada materi detik-detik proklamasi SMP Negeri 7 Penajam di siklus 1 Penelitian Tindakan Kelas ini, satu kelompok siswa menampilkan sosiodrama secara spontan bertema detik-detik proklamasi Indonesia. Penulis membuat observasi untuk menganalisa keadaan kelas saat pembelajaran berlangsung. Hasil observasi ditampilkan dalam table dibawah ini.

Tabel 1. Observasi siklus 1

\begin{tabular}{|c|l|c|c|c|}
\hline No & Aspek observasi & $\begin{array}{c}\text { Jumlah } \\
\text { siswa }\end{array}$ & Persentasi & Kategori \\
\hline 1 & Aktif Bertanya & 6 & $25 \%$ & Kurang \\
\hline 2 & Aktif Menjawab & 4 & $16.6 \%$ & Kurang \\
\hline 3 & $\begin{array}{l}\text { Kesungguh-an } \\
\text { Belajar }\end{array}$ & 13 & $54.2 \%$ & Cukup \\
\hline 4 & $\begin{array}{l}\text { Memperhatikan } \\
\text { Pem-belajaran }\end{array}$ & 16 & $66 \%$ & Cukup \\
\hline 5 & $\begin{array}{l}\text { Menyelesai-kan } \\
\text { Tugas dengan } \\
\text { tenang }\end{array}$ & 6 & $25 \%$ & Kurang \\
\hline
\end{tabular}

Berdasarkan table diatas, dari lima aspek observasi tidak satupun yang memenuhi kategori baik ( $75 \%$ keberhasilan) dalam pembelajaran. Dalam hal keaktifan siswa untuk memberikan pertanyaan, presentasinya adalah $25 \%$, atau dengan kata lain hanya 6 dari 24 siswa yang aktif bertanya. Untuk aspek menjawab pertanyaan baik dari guru maupun sesama siswa, hanya ada 4 orang siswa atau $16.6 \%$. Berikutnya adalah kesungguhan belajar (13 orang, 54.2\%) dan memperhatikan pembelajaran (16 orang, 66\%) yang kedua aspek tersebut dikategorikan cukup. Terakhir adalah menyelasaikan tugas dengan tenang yang hanya dilakukan oleh 6 orang anak (25\%). Hasil observasi ini dinilai tidak memuaskan karena sebagian besar aspek masih dalam kategori kurang baik, hanya dua aspek yang dinyatakan cukup baik dan tidak satupun yang mencapai kategori baik.

b. Hasil Belajar Siswa

Berdasarkan tes evaluasi yang penulis lakukan di akhir pengajaran, hasil analisis skor adalah sebagai berikut:

Tabel 2. Hasil belajar siswa siklus 1

\begin{tabular}{|l|l|l|l|l|}
\hline NO & $\begin{array}{l}\text { Interval } \\
\text { Skor }\end{array}$ & Kategori & Frekuensi & Presentase \\
\hline 1 & $<70$ & Kurang & 21 & $87.5 \%$ \\
\hline 2 & $71-80$ & Cukup & 3 & $12.5 \%$ \\
\hline
\end{tabular}

\begin{tabular}{|l|l|l|l|l|}
\hline 3 & $81-90$ & Baik & - & - \\
\hline 4 & $\begin{array}{l}91- \\
100\end{array}$ & $\begin{array}{l}\text { Sangat } \\
\text { Baik }\end{array}$ & - & - \\
\hline & Jumlah & & 24 & $100 \%$ \\
\hline
\end{tabular}

Tabel 3. Statistik skor hasil belajar siswa siklus 1

\begin{tabular}{|l|l|}
\hline Statistik & Nilai Statistik \\
\hline Subjek & 24 \\
\hline Skor ideal (nilai KKM) & 71 \\
\hline Skor tertinggi & 77 \\
\hline Skor terendah & 52 \\
\hline Rentan skor & 25 \\
\hline Skor rata-rata & 64.6 \\
\hline Jumlah siswa yang lulus KKM & $3(12.5 \%)$ \\
\hline $\begin{array}{l}\text { Jumlah siswa yang tidak lulus } \\
\text { KKM }\end{array}$ & $21(87.5 \%)$ \\
\hline
\end{tabular}

Dari table 4.2 dapat disimpulkan bahwa dari 24 responden, $87.5 \%$ dari responden (21 orang) mendapat nilai kurang, $12.5 \%$ (3 orang) mendapatkan nilai cukup dan juga dinyatakan lulus karena telah melampaui nilai KKM, sedangkan tidak ada satupun siswa yang mendapat nilai baik (81-90) dan sangat baik (90-100). Dapat dilihat dari table 4.3, untuk nilai KKM 71, hanya ada 3 orang (12.5\%) yang lulus tes evaluasi dan selebihnya, 21 orang tidak lulus $(87.5 \%)$, dengan nilai rata-rata di bawah KKM yaitu 64.6.

c. Refleksi

Pada pertemuan-pertemuan awal pelaksanaan siklus I semangat dan keaktifan siswa hampir tidak mengalami perubahan dibanding dengan sebelum pelaksanaan tindakan. Pada umumnya siswa hanya mendengar apa yang dijelaskan oleh guru tanpa ada pemahaman. Dalam hal ini, satu kelompok siswa menjadi pemeran dan selebihnya hanya menjadi penonton pasif saat sosiodrama ditampilkan.

Jika mengajukan pertanyaan siswa tampak lebih berani untuk memberikan jawaban lisan secara bersama-sama. Namun, jika siswa diminta menjawab secara perseorangan maka seperti yang dijabarkan sebelumnya, hanya sedikit orang saja yang berani memberikan pertanyaan dan juga menjawab pertanyaan baik dari guru ataupun sesame teman sekelas dalam sebuah diskusi.

Dari hasil pengamatan juga diketahui banyak siswa yang masih kurang bersemangat memperhatikan. Kemauan dan kesadaran siswa untuk memeperhatikan masih sangat kurang. Hal ini ditunjukkan ketika pekerjaan siswa yang sudah diambil secara acak kemudian ditanya lagi apa jawaban mereka ternyata pada umumnya mereka 
tidak bisa menjawab dari soal latihan yang diberikan ini juga ditemukan beberapa siswa yang masih kurang memahami point-point penting peristiwa detik-detik proklamasi. Hal ini dapat dilihat dari cara mereka mengerjakan soal yang masih tidak bias tenang dan berusaha mencari jawaban dari teman yang lain. Hasilnya, banyak dari mereka yang tidak dapat menjawab soal dengan balik, jawaban mereka yang masih salah atau kurang tepat. Sehingga masih sangat banyak siswa yang mendapat nilai di bawah nilai KKM.

Siswa yang mendapatkan nilai bagus biasanya adalah siswa yang cukup aktif dalam pembelajaran. Hal ini membuat penulis melanjutkan untuk merancang siklus berikutnya (siklus kedua). Dalam siklus kedua ini, akan ada perubahan cara belajar. Siswa akan lebih dimotivasi lagu untuk lebih aktif dengan cara menugaskan beberapa dari mereka untuk melakukan sosiodrama sendiri di depan kelas. Hal ini diharapkan agar suasana kelas lebih menarik dan tidak monoton, sehingga siswa dapat lebih mudah mengerti materi pembelajaran dan dapat menyerap pelajaran dengan baik.

\section{Siklus II}

a. Hasil Observasi

Dengan adanya perubahan dalam pengajaran di dalam siklus 2 ini, penulis menemukan peningkatan dalam hal keaktifan siswa. Suasana kelas menjadi semakin baik dari pada siklus sebelumnya (siklus 1). Hasil dari observasi di kelas dijabarkan dalam table 4.4 sebagi berikut:

Tabel 4. Observasi siklus 2

\begin{tabular}{|c|l|c|c|c|}
\hline $\begin{array}{c}\mathrm{N} \\
\mathrm{O}\end{array}$ & \multicolumn{1}{|c|}{$\begin{array}{c}\text { Aspek } \\
\text { observasi }\end{array}$} & $\begin{array}{c}\text { Jumlah } \\
\text { siswa }\end{array}$ & $\begin{array}{c}\text { Persent } \\
\text { asi }\end{array}$ & Kategori \\
\hline 1 & Aktif Bertanya & 11 & $45 \%$ & Kurang \\
\hline 2 & $\begin{array}{l}\text { Aktif } \\
\text { Menjawab }\end{array}$ & 12 & $50 \%$ & Cukup \\
\hline 3 & $\begin{array}{l}\text { Kesungguhan } \\
\text { Belajar }\end{array}$ & 19 & $79 \%$ & Baik \\
\hline 4 & $\begin{array}{l}\text { Memperhati- } \\
\text { kan } \\
\text { Pembelajaran }\end{array}$ & 21 & $87 \%$ & Sangat Baik \\
\hline 5 & $\begin{array}{l}\text { Menyelesaikan } \\
\text { Tugas dengan } \\
\text { tenang }\end{array}$ & 17 & $70 \%$ & Cukup \\
\hline
\end{tabular}

Berdasarkan table observasi diatas, dapat dilihat bahwa siswa mengalami peningkatan dalam hal aktif bertanya, dari $25 \%$ menjadi $45 \%$ (11 siswa), kemudian untuk aktif menjawab pertanyaan ada 12 siswa (50\%), selanjutnya peningkatan kesungguhan belar dan memperhatikan pembelajaran juga terlihat signifikan; 19 siswa (79\%) and 21 siswa (87\%), dan yang terakhir adalah menyelesaikan tugas dengan tenang yaitu $70 \%$ (17 orang). Dengan demikian dapat ditarik kesimpulan bahwa semua aspek meningkat dari sebelumnya, namun hal ini tidak dapat dikatakan memuaskan karena hanya ada masing-masing satu aspek yang dapat dikatakan sangat baik dan baik, sedangkan selebihnya aspek-aspek penilaian kondisi pembelajaran tersebut masih dikategorikan cukup dan bahkan kurang.

b. Hasil Belajar Siswa

Perubahan metode pembelajaran di siklus 2 ini memberikan peningkatan yang cukup signifikan. Selain hasil dari lembar observasi keadaan kelas yang dilakukan penulis dalam Penelitian Tindakan Kelas ini, hasil belajar siswa di siklus 2 ini juga terbilang meningkat. Ini dapat dibuktikan melalui tabel-tabel di bawah ini.

Tabel 5. Hasil belajar siswa siklus 2

\begin{tabular}{|l|l|l|l|l|}
\hline NO & Interval Skor & Kategori & Frekuensi & Presentase \\
\hline 1 & $<70$ & Kurang & 12 & $50 \%$ \\
\hline 2 & $71-80$ & Cukup & 12 & $50 \%$ \\
\hline 3 & $81-90$ & Baik & - & - \\
\hline 4 & $91-100$ & $\begin{array}{l}\text { Sangat } \\
\text { Baik }\end{array}$ & - & - \\
\hline & Jumlah & & 24 & $100 \%$ \\
\hline
\end{tabular}

Tabel 6. Statistik skor hasil belajar siswa siklus 2

\begin{tabular}{|l|l|}
\hline Statistik & Nilai Statistik \\
\hline Subjek & 24 \\
\hline Skor ideal (nilai KKM) & 71 \\
\hline Skor tertinggi & 80 \\
\hline Skor terendah & 65 \\
\hline Rentan skor & 15 \\
\hline Skor rata-rata & 71.7 \\
\hline Jumlah siswa yang lulus KKM & $12(50 \%)$ \\
\hline Jumlah siswa yang tidak lulus KKM & $12(50 \%)$ \\
\hline
\end{tabular}

Berdasarkan tabel 4.5 dan 4.6 di atas, ditemukan bahwa dari 12 dari 24 siswa (50\%) tingkat pemahaman belajar memahami peristiwa detik-detik proklamasi adalah kurang dan 50\% (12 orang) yang lain berada di kategori cukup. Dengan kata lain, tidak ada siswa yang beradi di kategori baik dan sangat baik dalam tes evaluasi di siklus ini. Skor tertinggi tes evaluasi siklus 2 adalah 80 , skor terendah 65 dan skor rat-rata $71.7 \%$. Jumlah siswa yang lulus adalah 12 orang $(50 \%)$, itu berarti yang tidak lulus juga 12 orang (50\%). Jumlah 
kelulusan siklus 2 meningkat dari siklus sebelumnya yang hanya $12.5 \%$, namun bukan berarti jumlah ini telah dinyatakan baik, karena persentasi keberhasilan yang telah ditetapkan adalah $75 \%$ dari siswa harus mendapatkan nilai 71 keatas.

c. Refleksi

Pada siklus II perhatian dan keaktifan siswa semakin memperlihatkan kemaajuan. Berdasarkan perubahan metode pembelajaran yang terjadi pada siklus ini, sebagian dari mereka harus mengambil bagian sebagai pemeran dalam sosiodrama di dalam kelas. Mereka yang ditunjuk secara acak harus menghapal teks naskah drama mereka dengan karakter masing-masing dan tampil berani berekspresi di depan temantemannya.

Keberanian siswa untuk bertanya dan menanggapi materi yang diberikan juga mengalami kemajuan jika dibandingkan dengan siklus I. Hal ini terjadi karena seiringnya siswa lebih tertarik terhadap scenario karena yang berperan adalah teman mereka sendiri. Jika pada siklus I dimonopoli oleh beberapa siswa saja, maka siklus II siswa telah lebih banyak yang berani menanggapi dengan mengangkat tangan dan menjawab soal yang diberikan dengan benar. Secara umum hasil yang telah dicapai setelah pelaksanaan tindakan dengan penerapan model pembelajaran menggunakan metode sosiodrama ini mengalami peningkatan, baik dari segi perubahan sikap siswa, keaktifan dan perhatian siswa maupun dari segi kemampuan siswa menyelesaikan soal PPKn mengenai peristiwa detik-detik proklamasi secara individu. Sehingga tentunya telah memberikan dampak positif terhadap peningkatan hasil belajar siswa.

Namun hal ini tidak berarti Penelitian Tindakan Kelas (PTK) ini sudah berakhir, karena walaupun hasil observasi dan tes evaluasi telah meningkat, persentasi kesuskesan semua aspek belum mencapai 75\%. Untuk mencapai tahap itu, perlu adanya siklus ketiga, dimana modifikasi terhadap metode pembelajaran sosiodrama akan diberi sedikit modifikasi. Selain mendorong siswa untuk lebih termotivasi dan aktif, guru dalam penelitian ini akan meminta semua siswa untuk berpartisipasi berperan sosiodrama di dalam kelas, karena berdasarkan tes evaluasi, siswa yang terlibat langsung dalam sosiodrama adalah siswasiswa yang mendapat nilai yang lebih baik. Untuk itu, keterlibatan semua siswa dalam sosiodrama pada siklus ketiga diharapkan dapat membuat semua siswa mendapatkan nilai tes evaluasi yang memenuhi standar KKM minimal $75 \%$ dari keseluruhan siswa.

\section{Siklus III}

a. Hasil Observasi

Dalam siklus 3 ini, terdapat modifikasi lain dari metode sosiodrama yang diterapkan dalam pembelajaran PPKn materi Detik-detik Proklamasi; semua anak yang tebentuk dari dua kelompok menampilkan sosiodrama mengenai detik-detik proklamasi Indonesia di dalam kelas. Hal ini menimbulkan adanya peningkatan keadaan kelas yang dapat dianalisis dari hasil observasi. Hasil dari lembar observasi tersebut dapat dilihat di tabel 7 sebagai berikut:

Tabel 7. Observasi siklus 3

\begin{tabular}{|c|l|c|c|c|}
\hline NO & Aspek observasi & $\begin{array}{c}\text { Jumlah } \\
\text { siswa }\end{array}$ & Persentasi & Kategori \\
\hline 1 & Aktif Bertanya & 19 & $79 \%$ & Baik \\
\hline 2 & Aktif Menjawab & 20 & $83 \%$ & Baik \\
\hline 3 & $\begin{array}{l}\text { Kesungguhan } \\
\text { Belajar }\end{array}$ & 21 & $87.5 \%$ & $\begin{array}{c}\text { Sangat } \\
\text { Baik }\end{array}$ \\
\hline 4 & $\begin{array}{l}\text { Memperhatikan } \\
\text { Pembelajaran }\end{array}$ & 22 & $91.6 \%$ & $\begin{array}{c}\text { Sangat } \\
\text { Baik }\end{array}$ \\
\hline 5 & $\begin{array}{l}\text { Menyelesaikan } \\
\text { Tugas dengan } \\
\text { tenang }\end{array}$ & 24 & $100 \%$ & $\begin{array}{c}\text { Sangat } \\
\text { Baik }\end{array}$ \\
\hline
\end{tabular}

Tabel diatas menjelaskan bahwa keaktifan siswa dalam bertanya bertambah menjadi 79\% (19 orang), sedangkan keaktifan dalam menjawab adalah $83 \%$ (20 orang), kesungguhan dalam belajar dan memperhatikan pembelajaran masing-masing $87.5 \%$ (21 orang) dan 91.6\% (22 orang), dan yang paling signifikan adalah menyelesaikan tugas dengan tenang yaitu $100 \%$ dari seluruh siswa (24 orang). Dapat disimpulkan bahwa semua aspek dari observasi meningkat dengan baik dan semua presentasi keberhasilan penelitian ini dalam hal keadaan kelas dalam kegiatan belajar detik-detik proklamasi telah mencapai lebih dari target yaitu $75 \%$.

b. Hasil Belajar siswa

Setelah diterapkan tindakan, pada siklus 2 berupa model pembelajaran menggunakan metode sosiodrama, siklus terakhir (siklus 3 ) ini pun masih menggunakan metode yang sama namun dengan sedikit modifikasi, yaitu semua siswa harus terlibat dalam memerankan tokoh-tokoh detikdetik proklamasi yang dibentuk dari 2 kelompok 
drama. Hal ini dilakukan agar semua siswa dapat memahami peristiwa tersebut dengan lebih mendalam. Adapun hasil belajar memahami peristiwa detik-detik proklamasi yang dicapai siswa kelas VIID SMPN 7 PPU melalui tes evaluasi berupa essay adalah sebagai berikut.

$\mathrm{T}$

abel 8. Distribusi, Frekuensi dan Presentase skor hasil belajar siswa siklus 3

\begin{tabular}{|c|c|c|c|c|}
\hline $\mathrm{NO}$ & $\begin{array}{l}\text { Interval } \\
\text { Skor } \\
\end{array}$ & Kategori & Frekuensi & Presentase \\
\hline 1 & $<70$ & Kurang & 3 & $12.5 \%$ \\
\hline 2 & $71-80$ & Cukup & 15 & $62.5 \%$ \\
\hline 3 & $81-90$ & Baik & 4 & $16.7 \%$ \\
\hline 4 & $91-100$ & $\begin{array}{l}\text { Sangat } \\
\text { Baik }\end{array}$ & 2 & $8.3 \%$ \\
\hline \multicolumn{3}{|c|}{ Jumlah } & 24 & $100 \%$ \\
\hline
\end{tabular}

Tabel 9. statistik skor hasil belajar siswa siklus 3

\begin{tabular}{|l|l|}
\hline Statistik & Nilai Statistik \\
\hline Subjek & 24 \\
\hline Skor ideal & 71 \\
\hline Skor tertinggi & 87 \\
\hline Skor terendah & 68 \\
\hline Rentan skor & 19 \\
\hline Skor rata-rata & 78 \\
\hline $\begin{array}{l}\text { Jumlah siswa yang lulus } \\
\text { KKM }\end{array}$ & $21(87.5 \%)$ \\
\hline $\begin{array}{l}\text { Jumlah siswa yang tidak } \\
\text { lulus KKM }\end{array}$ & $3(12.5 \%)$ \\
\hline
\end{tabular}

Berdasarkan table 4.8 dikemukakan bahwa dari 24 siswa kelas VIID SMPN 7 PPU terdapat 3 orang siswa atau $12.5 \%$ mendapat nilai kategori kurang, 15 orang siswa atau $62.5 \%$ pada kategori sangat cukup, 4 orang $(16.7 \%)$ mendapat kategori baik, dan terakhir 2 orang siswa $(8.3 \%)$ mendapat kategori sangat baik. Dan sebanyak 21 siswa $(87.5 \%)$ siswa lulus KKM, sedangkan sebanyak $12.5 \%$ siswa (3 orang) tidak lulus KKM. Hal ini berarti persentasi keberhasilan yang lebih dari $75 \%$ dari siswa telah terlampaui.

Tabel 4.9 menunjukkan bahwa skor ratarata hasil belajar siswa dalam memahami peristiwa detik-detik Proklamasi pada siklus III adalah 78 dari skor ideal 71. Nilai tertinggi adalah 87 dan skor terendah adalah 68 dengan rentang skor 19 , yang berarti skor rata-rata hasil belajar memahami peristiwa detik-detik proklamasi yang dicapai siswa kelas VIID SMPN 7 PPU telah melampaui skor ideal (nilai KKM).

c. Refleksi

Pada siklus ini, segala aspek keaktifan siswa semakin memperlihatkan semakin membaik.
Berdasarkan perubahan metode pembelajaran yang terjadi pada siklus ini, seluruh siswa harus mengambil bagian sebagai pemeran dalam sosiodrama di dalam kelas. Ini ditujukan agar seluruh siswa dapat memahami secara mendalam tentang detik-detik proklamasi Indonesia dengan cara menguaisai naskah sosiodrama yang mereka tampilkan di dalam kelas bersama kelompok masing-masing.

Hasilnya, keberanian siswa untuk bertanya dan menanggapi materi yang diberikan juga mengalami kemajuan jika dibandingkan dengan siklus 1 dan 2. Segala aspek dari hasil yang telah dicapai setelah pelaksanaan tindakan dengan penerapan model pembelajaran menggunakan metode sosiodrama ini mengalami peningkatan, baik dari segi perubahan sikap siswa, maupun dari segi kemampuan siswa menyelesaikan soal PPKn mengenai peristiwa detik-detik proklamasi melalui tes evaluasi.

Tabel 10. Distribusi Frekuensi dan Presentase hasil belajar siswa siklus 1-3

\begin{tabular}{|c|l|c|c|c|c|c|c|}
\hline No & \multicolumn{1}{|c|}{$\begin{array}{c}\text { Aspek } \\
\text { observasi }\end{array}$} & \multicolumn{3}{|c|}{ Frekuensi } & \multicolumn{3}{|c|}{ Persentasi } \\
\cline { 3 - 8 } & $\begin{array}{c}\text { Siklu } \\
\text { s 1 }\end{array}$ & $\begin{array}{c}\text { Siklu } \\
\text { s 2 }\end{array}$ & $\begin{array}{c}\text { Siklu } \\
\text { s 3 }\end{array}$ & $\begin{array}{c}\text { Siklu } \\
\text { s 1 }\end{array}$ & $\begin{array}{c}\text { Siklu } \\
\text { s 2 }\end{array}$ & $\begin{array}{c}\text { Siklu } \\
\text { s 3 }\end{array}$ \\
\hline 2 & $\begin{array}{l}\text { Aktif } \\
\text { Bertanya }\end{array}$ & 6 & 11 & 19 & $25 \%$ & $45 \%$ & $79 \%$ \\
\hline 3 & $\begin{array}{l}\text { Aktif } \\
\text { Menjawab }\end{array}$ & 4 & 12 & 20 & $\begin{array}{c}16.6 \\
\%\end{array}$ & $50 \%$ & $83 \%$ \\
\hline 4 & $\begin{array}{l}\text { Kesungguha } \\
\text { n Belajar }\end{array}$ & 13 & 19 & 21 & $\begin{array}{c}54.2 \\
\%\end{array}$ & $79 \%$ & $\begin{array}{c}87.5 \\
\%\end{array}$ \\
\hline $\begin{array}{l}\text { Memperhati- } \\
\text { kan } \\
\text { Pembelajara } \\
\text { n }\end{array}$ & 16 & 21 & 22 & $66 \%$ & $87 \%$ & $\begin{array}{c}91.6 \\
\%\end{array}$ \\
\hline $\begin{array}{l}\text { Menyelesai- } \\
\text { kan Tugas } \\
\text { dengan } \\
\text { tenang }\end{array}$ & 6 & 17 & 24 & $25 \%$ & $70 \%$ & $\begin{array}{c}100 \\
\%\end{array}$ \\
\hline & Jumlah & 24 & 24 & 24 & $\begin{array}{c}100 \\
\%\end{array}$ & $\begin{array}{c}100 \\
\%\end{array}$ & $\begin{array}{c}100 \\
\%\end{array}$ \\
\hline
\end{tabular}

Tabel diatas menyatakan bahwa baik dari aspek pertama sampai terakhir, semua mengalami peningkatan persentasi dari siklus 1 sampai siklus 3. Dalam aspek aktif bertanya, dari siklus 1 sampai siklus 2 mengalami kenaikan 20\% (dari $25 \%$ ke $45 \%$ ), dan dari siklus 2 sampai siklus 3 peningkatan sebanyak 34\% (dari 45\% ke 79\%). Untuk aspek aktif menjawab, dari siklus 1 ke siklus 2 meningkat $33.4 \%(16.6 \%$ ke $50 \%)$ dan siklus 2 ke siklus 3 adalah 33\% (dari 50\% menjadi $83 \%$ ). Kesungguhan belajar meningkat dari siklus 
1 ke siklus 2 yaitu $24.8 \%$ (54.2\% sampai $79 \%$ ), dan dari siklus 2 ke siklus 3 adalah $8.5 \%$ (79\% ke 87.5\%). Memperhatikan pelajaran dari siklus $1 \mathrm{ke}$ siklus 2 meningkat sebanyak 21\% (dari 66\% ke $87 \%$ ) dan dari siklus 2 ke siklus 3 peningkatan $4.6 \%$ (dari $87 \mathrm{ke} 91.6 \%$ ). Dan yang terakhir menyelesaikan tugas peningkatannya sebanyak $47 \%$ (dari $25 \%$ ke $70 \%$ ) dan dari siklus 2 ke siklus 3 adalah 30\% (dari $70 \%$ ke 100\%). Dari penjabaran diatas dapat disimpulkan bahwa di siklus 3, semua aspek telah mencapai persentasi keberhasilan yaitu $75 \%$. Metode pembelajaran sosiodrama dianggap dapat membantu meningkatkan keaktifan dan motivasi dan keseriusan siswa kelas VIID SMP Negeri 7 Penajam untuk memahami pelajaran PPKn dalam materi detik-detik proklamasi.

Selanjutnya tabel 4.11 dan 4.12 memperlihatkan peningkatan hasil belajar siswa setelah digunakan model pembelajaran menggunakan metode sosiodrama dalam proses belajar mengajar pada tes siklus 1 , siklus 2 dan siklus 3.

Tabel 11 Distribusi Frekuensi dan Presentase hasil belajar siswa siklus 1 - 3

\begin{tabular}{|c|c|c|c|c|c|c|c|c|}
\hline \multirow{2}{*}{$\begin{array}{l}\mathrm{N} \\
\mathrm{O}\end{array}$} & \multirow[b]{2}{*}{ Skor } & \multirow[b]{2}{*}{ Kategori } & \multicolumn{3}{|c|}{ Frekuensi } & \multicolumn{3}{|c|}{ Persentasi } \\
\hline & & & $\begin{array}{l}\text { Sikl } \\
\text { us } 1\end{array}$ & $\begin{array}{l}\text { Sikl } \\
\text { us } 2\end{array}$ & $\begin{array}{l}\text { Sikl } \\
\text { us } 3\end{array}$ & $\begin{array}{l}\text { Sikl } \\
\text { us } 1\end{array}$ & $\begin{array}{l}\text { Sikl } \\
\text { us } 2\end{array}$ & $\mathrm{~S}$ \\
\hline 1 & $<70$ & $\begin{array}{l}\text { Kurang } \\
\text { (TL) }\end{array}$ & 21 & 12 & 3 & $\begin{array}{l}87.5 \\
\%\end{array}$ & $\begin{array}{l}50 \\
\%\end{array}$ & $\begin{array}{l}1 \\
0\end{array}$ \\
\hline 2 & $\begin{array}{ll}71- \\
80\end{array}$ & Cukup (L) & 3 & 12 & 15 & $\begin{array}{l}12.5 \\
\%\end{array}$ & $\begin{array}{l}50 \\
\%\end{array}$ & $\begin{array}{l}6 \\
\%\end{array}$ \\
\hline 3 & $\begin{array}{ll}81- \\
90\end{array}$ & Baik (L) & - & - & 4 & - & - & $\begin{array}{l}1 \\
0\end{array}$ \\
\hline 4 & $\begin{array}{l}91- \\
100\end{array}$ & $\begin{array}{l}\text { Sangat } \\
\text { Baik (L) }\end{array}$ & - & - & 2 & - & - & 8 \\
\hline \multicolumn{3}{|c|}{ Jumlah } & 24 & 24 & 24 & $\begin{array}{l}100 \\
\%\end{array}$ & $\begin{array}{l}100 \\
\%\end{array}$ & 1 \\
\hline
\end{tabular}

Tabel 12. statistik skor hasil belajar siswa siklus 1 $-3$

\begin{tabular}{|l|l|l|l|l|}
\hline \multirow{2}{*}{ No } & \multirow{2}{*}{ Statistik } & \multicolumn{3}{|c|}{ Nilai Statistik } \\
\cline { 3 - 5 } & & Siklus 1 & Siklus 2 & Siklus 3 \\
\hline 1 & Skor tertinggi & 77 & 80 & 87 \\
\hline 2 & Skor terendah & 52 & 65 & 68 \\
\hline 3 & Rentan skor & 25 & 15 & 19 \\
\hline 4 & Skor rata-rata & 64.6 & 71.7 & 78 \\
\hline 5 & $\begin{array}{l}\text { Jumlah siswa } \\
\text { yang lulus KKM }\end{array}$ & 3 & 12 & 21 \\
$(12.5 \%)$ & $(50 \%)$ & $(87.5 \%)$ \\
\hline 6 & $\begin{array}{l}\text { Jumlah siswa } \\
\text { yang tidak lulus } \\
\text { KKM }\end{array}$ & $\begin{array}{l}21 \\
(87.5 \%)\end{array}$ & $\begin{array}{l}12 \\
(50 \%)\end{array}$ & \begin{tabular}{l}
$(12.5 \%)$ \\
\hline
\end{tabular}
\end{tabular}

Dari tabel 4.11 dan 4.12 diatas dapat disimpulkan bahwa persentasi kelulusan siswa yang mengikuti tes evaluasi detik-detik proklamasi secara konsisten terus bertambah dari siklus 1, siklus 2 dan sampai siklus ke 3. Dari siklus pertama ke siklus kedua, peningkatan kelulusan adalah $37.5 \%$ (dari $12.5 \%$ sampai $50 \%$ ) dan skor rata-rata meningkat dari 64.6 ke 71.1, peningkatan ini sudah sangat signifikan namun masih belum mencapai batas keberhasilan lulus 75\% dari 24 siswa. Lalu terjadi peningkatan signifikan lagi dari siklus 2 ke siklus 3 yaitu sebanyak 37.5\% lagi $(50 \%$ ke $87.5 \%)$ dengan skor rata-rata yang meningkat dari 71.1 menjadi 78. Hasil belajar siklus 3 ini dianggap baik karena persentasi kelulusannya telah mencapai $75 \%$.

Berdasarkan hasil analisis deskriptif dapat disimpulkan bahwa metode pengajaran dengan melibatkan secara langsung siswa dalam peran sosiodrama adalah hal yang baik untuk meningkat pemahaman siswa dalam memahami materi pelajaran secara mendalam. Dalam siklus 1, satu kelompok siswa memerankan sosiodrama secara langsung sedangkan yang lain menjadi penonton. Persentasi kelulusan siklus ini sangat kecil dan suasana kelas juga tidak kondusif; saat kelas membutuhkan suasana yang aktif dengan sesi tanya-jawab, para siswa bertindak sebaliknya yaitu Sjkbsif, dan saat kelas seharusnya tenang disaat us 3 gerjakan tes evaluasi diakhir pembelajaran, \% kelas jadi ribut karena siswa mengerjakan tes 6desngan tidak tenang akibat kurang pemahaman \%an berusaha berdiskusi dengan teman sekitarnya 1 Gintuk sebuah tugas individu. Pada siklus 2, Metode pembelajaran diubah dengan melibatkan osebagian siswa yang pada siklus sebelumnya 1penjadi penonton untuk memerankan tokoh-tokoh \%pahlawan proklamasi. Hal ini menghasilkan suasana belajar dan hasil belajar yang lebih baik karena keterlibatan seluruh siswa dalam sosiodrama dinilai lebih menarik bagi penonton dan bagi pemeran sendiri yang berusaha menghapal naskah drama dan karakter pahlawan yang mereka perankan. Namun hal itu tidak membuat siklus 2 ini langsung dinyatakan berhasil, karena pada akhirnya suasana kelas yang dianalisa dari hasil observasi dan hasil tes evaluasi siswa yang dianalisa belum mencapai $75 \%$ keberhasilan. Dalam siklus 3, metode pembelajaran sosiodrama dimodifikasi untuk mencapai hasil yang maksimal. Berdasarkan analisa siklus 2, siswa-siswa yang mendapatkan nilai yang baik biasanya adalah anak-anak yang 
terlibat secara langsung dalam memerankan tokohtokoh pahlawan. Oleh sebab itu, di siklus 3, penulis meminta seluruh siswa untuk terlibat dalam sosiodrama yang terbagi menjadi dua kelompok. Hasilnya, situasi kelas semakin membaik lagi, semua aspek observasi dan tingkat kelulusan hasil belajar siswa lebih dari $75 \%$.

Dengan meningkatnya aktivitas siswa dalam proses belajar-mengajar yang juga disertai dengan terjadinya peningkatan ketuntasan hasil belajar siswa dari siklus 1 ke siklus 2 dan siklus 3, maka dapat dikatakan bahwa pembelajaran dengan menggunakan model pembelajaran menggunakan metode bermain drama dapat meningkatkan hasil belajar PPKn khususnya memahami peristiwa detik-detik proklamasi.

\section{Kesimpulan}

Berdasarkan hasil penelitian dari pembahasan sebelumnya maka dapat disimpulkan bahwa penerapan model pembelajaran menggunakan metode pembelajaran bermain drama/ sosiodrama dapat meningkatkan hasil belajar PPKn Siswa kelas VIID SMPN 7 PPU yang ditandai dengan adanya peningkatan sekor rata-rata (mean) dari siklus 1 ke siklus 2 dan siklus 3, yaitu dari $64.4 \%$ menjadi $71.1 \%$ dan yang terakhir $78 \%$ dari sekor ideal 71 . Penelitian ini juga dinyatakan berhasil jika $75 \%$ dari siswa lulus, pada siklus 1 dimana siswa menonton video sosio drama tentang detik-detik proklamasi, persentasi kelulusan adalah $12.5 \%$, pada siklus 2 sebagian siswa terlibat dalam pemeran sosiodrama di kelas, dan tingkat kelulusan 50\%, dan di siklus 3, semua siswa turut berperan secara langsung dalam

\section{Daftar Pustaka}

Anderson L., dan Krathwohl D.R. 2010. Kerangka Landasan untuk Pembelajaran, Pengajaran, dan Asesmen Revisi Taksonomi Pendidikan Bloom. Yogyakarta: Pustaka Pelajar.

Arikunto, Suharsimi. 2010. Prosedur Penelitian Suatu Pendekatan Praktik. Jakarta: Rineka Cipta.

Endraswara, Suwardi. 2011. Metode Pembelajaran Drama: Apresiasi, Ekspresi, dan. Pengkajian. Yogyakarta: KAPS

Kemendikbud. 2017. Permendikbud Nomor 3 Tahun 2017 Penilaian Hasil Belajar pemeran sosiodrama dan persentasi kelulusannya adalah $87.5 \%$.

Dengan pembelajaran menggunakan metode bermain drama/sosiodrama menunjukkan bahwa terdapat aktivitas siswa yang mengalami peningkatan seperti siswa

yang lebih semangat dan memperhatikan materi, siswa yang mengajukan tanya jawab, siswa yang serius mengikuti pembelajaran dan siswa yang mengerjakan test akhir dengan tenang dan baik. Adapun aktivitas siswa seperti siswa meminta bimbingan pada guru dan siswa yang melakukan tindakan lain pada saat pembelajaran berlangsung mengalami penurunan. Dengan menggunakan tes setiap siklus siswa terdapat peningkatan hasil pembelajaran dapat disimpulkan menggunakan metode bermain drama dapat diketahui bahwa siswa mengalami peningkatan dari siklus I ke siklus II lanjut kesiklus III.

Sehubungan dengan penelitian yang dilakukan, maka peneliti memberikan saran yang berkaitan dengan usaha peningkatan hasil belajar siswa. Dari kesimpulan yang diperoleh maka penulis menyarankan sebaiknya guru menerapkan variasi-variasi dalam pembelajaran, agar mengurangi kejenuhan kepada siswa dalam menerima pelajaran. Varias pembelajaran drama yang terbukti dapat meningkatkan hasil belajar ini dapat diterapkan dalam kegiatan belajar-mengajar, dan variasi-variasi pembelajaran lain juga dapat diteliti oleh penulis berikutnya, agar perkembangan pendidikan di Indonesia semakin meningkat.

oleh Pemerintah dan Penilaian Hasil Belajar oleh Satuan Pendidikan. Jakarta: Kemendikbud.

Kementerian Pendidikan dan Kebudayaan. 2016. Pendidikan Pancasila dan Kewarganegaraan:edisi revisi 2016 Jakarta: Kemendikbud

Kementerian Pendidikan dan Kebudayaan. 2013. Pendidikan Pancasila dan Kewarganegaraan: Buku Guru. Bandung: PT Sarana Pancakarya Nusa Kementerian Pendidikan dan Kebudayaan. 2013. Pendidikan Pancasila dan 
Kewarganegaraan: Buku Siswa. Bandung: PT Sarana Pancakarya Nusa

Kemmis, S. \& McTaggart, R.1988. The Action Researh Reader. Victoria, Deakin: University Press

Kemmis, S., \& McTaggart, R. 1992. The Action Research Planner (3rd ed.). Geelong Deakin University Press.

Kosasih, (2013). Materi drama Indonesia. Bandung: Angkasa.

Nurgiyantoro, Burhan. 2007. Teori Pengkajian Fiksi. Yogyakarta: Gadjah Mada

Munirah. 2007. Dasar Keterampilan Menulis. Makassar: Fakultas Keguruan dan Ilmu Pendidikan Universitas Muhammadiyah Makassar

Pramudya, Y.P. 2018. Analisis Struktur Dan Tekstur Naskah Drama "Pada Suatu
Hari” Karya Arifin C. Noer. Universitas sanata Dharma

Sanjaya, H. Wina. 2012. Strategi Pembelajaran Berorientasi Standar Proses Pendidikan. Jakarta: kencana Prenada Media Group

Sugiyono. 2014. Metode Penelitian Pendidikan Pendekatan Kuantitatif, Kualitatif Dan $R \& D$. Bandung: Alfabeta.

Suparno, Paul. 2008. Riset Tindakan untuk Pendidikan. Jakarta: PT Gramedia Widia Sarana Indonesia.

Supriyati, Ninik. 2018. Mixed Methods Metode Penelitian Gabungan (Mixed Methods). Surabaya: Widyaiswara BDK

http://ditpsmp.kemdikbud.go.id/erapor/file/Pand uan-Penilaian-SMP-Revisi-2017.pdf

(Diakses Januari 2019) 